\title{
PENGARUH ANALISIS JABATAN DAN PENGEMBANGAN KARIR MELALUI KOMPETENSI TERHADAP KINERJA PEGAWAI KANTOR KEMENTERIAN AGAMA KABUPATEN TEBO
}

\author{
Arna Suryani, Rini Susanti \\ Dosen Fakultas Ekonomi Universitas Batanghari Jambi
}

\begin{abstract}
The purpose of this study is to determine the effect of Job Analysis and Competency Career Development Through Employee Performance Against Religious Affairs Office of Tebo with a population of 31 personnel. The results showed, in the school environment to support Based on the research results, TCR variable job analysis (X1) of 1844, career development (X2) amounted to 1,210, competence (Y) of 1847, and the performance of employees (Z) of 1,348. Effect of X1 to $Y$ at 0.682, X2 to $Y$ at 0.173, ANOVA value X1, X2 to $Y$ at 27.746. Meanwhile, the influence of the $Z$ amounted to $0.701 X 1, X 2$ to $Z$ of 0.280 , ANOVA values X1 and X2 to Z at 81.229. Meanwhile, the effect of job analysis and career development together with the competence of $38.4859 \%$.
\end{abstract}

Keyword : Position Analysis, Career Development, Competency, Employee Performance.

\section{PENDAHULUAN}

Penerapan analisis jabatan tidak hanya digunakan oleh perusahaan-perusahaan besar saja, karena pada dasarnya setiap organisasi membutuhkan adanya analisis jabatan guna menunjang kinerja organisasi. Akan tetapi, besar kecilnya tingkat kebutuhan akan adanya analisis jabatan juga tergantung pada kebutuhan organisasi tersebut. Gibson, Ivancevich, dan Donelly, (2003:38), menjelaskan bahwa analisis jabatan adalah proses pengambilan keputusan yang menerjemahkan faktor tugas, manusia, dan teknologi menjadi sebuah desain pekerjaan. Artinya, dalam analisis jabatan seorang pimpinan dapat mengetahui kelebihan maupun kekurangan dari bawahannya dimana pada akhirnya akan menentukan dimana ia akan ditempatkan sesuai dengan kemampuannya.

Sementara, karier tidak hanya menunjukkan perubahan pekerjaan gerak vertikal naik dalam suatu organisasi. Meskipun sebagian besar karywan masih berusaha mencapai kemajuan, akan tetapi banyaknya orang yang menolak pekerjaan yang lebih berat tanggungjawabnya untuk tetap dalam jabatan yang sekarang dipegang dan disukainya. Hal ini dikarenakan, Pengembangan karier seperti promosi sangat diharapkan oleh setiap karyawan karena dengan pengembangan ini akan mendapatkan hak-hak yang lebih baik dari apa yang diperoleh sebelumnya baik material maupun non material.

Mathis dan Jackson (2007:27), menjelaskan definisi pengembangan karier sebagai pertumbuhan kemampuan yang terjadi jauh melampaui apa yang dituntut dalam suatu pekerjaan dan dalam hal ini sumber daya manusia berperan penting dalam maju mundurnya suatu organisasi. Hal ini dikarenakan, pengembangan karier merupakan sebuah proses dalam peningkatan pelatihan kerja baik yang bersifat teknis maupun manajerial. 
Setiap organisasi dibentuk untuk mencapai tertentu dan apabila tercapai baru dapat dikatakan keberhasilan seorang pemimpin dalam meningkatkan kinerja para bawahannya. Oleh karena itu, untuk mencapai keberhasilan diperlukan landasan yang kuat salah satunya yaitu kompetensi, baik kompetensi pegawai, pemimpin, dan organisasi dengan begitu dapat diketahui bahwa kompetensi sangat penting untuk mencapai suatu tujuan dalam organisasi dengan sukses.

Wibowo (2010:324), menjelaskan bahwa kompetensi adalah suatu kemampuan untuk melaksanakan atau melakukan suatu pekerjaan maupun tugas yang dilandasi atas keterampilan dan pengetahuan, serta didukung oleh sikap kerja yang dituntut oleh pekerjaan tersebut. Rivai (2005:14), menjelaskan bahwa kinerja adalah hasil atau tingkat keberhasilan seseorang secara keseluruhan selama periode tertentu didalam melaksanakan tugas dibandingkan dengan berbagai kemungkinan, seperti standar hasil kerja, target atau sasaran atau kriteria yang telah ditentukan terlebih dahulu dan telah disepakati bersama.

Berdasarkan rekapitulasi kualifikasi pendidikan dan kesempatan dalam pengembangan karir dapat dikatakan bahwa masih banyak kesenjangan antara pemenuhan jumlah pegawai dengan kuota serta pemberian kesempatan pegawai yang ada pada setiap bidang atau seksi jabatan yang ada pada Kantor Kementerian Agama Kabupaten Tebo untuk dapat mengembangkan karir mereka. Pada akhirnya, cenderung para pegawai yang ada di Kantor Kementerian Agama Kabupaten Tebo masih memiliki jenjang pendidikan D3 dan SMA.

Sementara, lebih jauh pencapaian target dan realisasi DIPA Satker Kantor Kementerian Agama Kabupaten Tebo masih berada dibawah 100\%. Hal ini harus menjadi pekerjaan rumah bagi pimpinan yang terkait agar di masa-masa yang akan datang mampu meningkatkan kembali daya saing para pegawainya, serta meningkatkan mutu dan kualitas pelayanan dari Kantor Kementerian Agama Kabupaten Tebo itu sendiri.

\section{Tinjauan Pustaka}

\section{Analisis Jabatan}

Segala upaya yang dilakukan dalam upaya meningkatan kinerja pegawai dimungkinkan akan lebih optimal hasilnya bila didahului dengan adanya analisis jabatan yang benar dan optimal terlebih dahulu. Terlebih pada organisasi yang mempunyai banyak lini dalam struktur organisasinya dan sangat kompleks permasalahan yang dihadapi.

Jusuf (2001:28), menyatakan bahwa analisis jabatan adalah suatu proses mempelajari dan mengumpulkan informasi-informasi yang berkembang dengan operasi-operasi pelaksanaan dan tanggung jawab dari suatu jabatan tertentu. Sedangkan, Sirait (2006:46), menjelaskan bahwa analisis jabatan adalah proses untuk memperoleh informasi serinci mungkin mengenai fakta-fakta yang terjadi, yang diperlukan guna menyelesaikan tugas-tugas yang ada dalam suatu jabatan.

Dengan demikian, maka dapat dijelaskan bahwa analisis jabatan adalah cara yang sistematis yang mampu mengindentifikasi serta menganalisa persyaratan apa saja yang diperlukan dalam sebuah pekerjaan serta personel yang dibutuhkan dalam suatu pekerjaan sehingga sumber daya manusia yang dipilih mampu melaksanakan pekerjaan itu dengan baik.

\section{Pengembangan Karir}


Dalam unsur pekerjaan, karier merupakan salah satu faktor yang dapat memacu seseorang atau yang sering disebut dengan karyawan maupun pegawai dalam sebuah organisasi melaksanakan tanggung jawab dan beban kerja dengan sebaik mungkin. Hal ini dikarenakan, dengan adanya kenaikan karier, maka kebutuhan mereka pun terpenuhi dan merasa bahwa produktivitas kerja mereka diperhatikan oleh pimpinan dan pihak manajemen.

Feldam (2005:70) menyatakan istilah karier tidak hanya berhubungan dengan individu yang mempunyai pekerjaan yang statusnya tinggi atau yang mendapat kemajuan cepat. Istilah karier sedikit banyak telah didemokratisasi. Saat ini karier menunjukkan rangkaian atau urutan pekerjaan/jabatan yang dipegang oleh orang-orang selama riwayat pekerjaannya, tidak pandang tingkat pekerjaan atau tingkat organisasinya.

Dengan demikian, maka dapat disimpulkan bahwa karier merupakan perjalanan yang dilalui seseorang selama hidupnya. karier menentukan tujuan untuk pengembangan karyawan secara sistematis, sehingga tujuan karier telah disetujui, maka kegiatan pengembangan karier dapat dipilih dan disalurkan dalam suatu arah yang berarti bagi individu maupun bagi organisasi.

\section{Kompetensi}

Kompetensi sebagai kemampuan seseorang untuk menghasilkan pada tingkat yang memuaskan ditempat kerja, termasuk diantaranya kemampuan seseorang untuk mentransfer dan mengaplikasikan keterampilan dan pengetahuan tersebut dalam situasi yang baru dan meningkatkan manfaat yang disepakati bersama.

Kessler (2011:15), menjelaskan bahwa kompetensi merupakan karakteristik utama yang dimiliki oleh orang-orang yang paling sukses dalam setiap bidang profesi yang telah membantunya untuk berhasil. Sedangkan, Rivai (2005:65), menjelaskan bahwa kompetensi adalah sesuatu yang orang bawa bagi suatu pekerjaan dalam bentuk dan tingkatan perilaku yang berbeda.

Dengan demikian, dapat disimpulkan bahwa kompetensi merupakan suatu kemampuan untuk melakukan sesuatu pekerjaan atau tugas yang didasari oleh keterampilan dan pengetahuan yang didukung oleh sikap tanggungjawab.

\section{Kinerja Pegawai}

Kinerja (performance) adalah gambaran mengenai tingkat pencapaian pelaksanaan suatu kegiatan/program/kebijakan dalam mewujudkan sasaran, tujuan, misi dan visi organisasi yang tertuang dalam perencanaan strategis suatu organisasi. Istilah kinerja sering digunakan untuk menyebut prestasi atau tingkat keberhasilan individu maupun kelompok.

Bernadin dan Russell (2002:135), berpendapat bahwa kinerja pegawai merupakan catatan yang dihasilkan dari fungsi suatu pekerjaan tertentu atau kegiatan selama periode waktu tertentu. Dengan adanya catatan tersebut pimpinan dapat mengetahui sejauhmana kinerja dari para pegawainya dalam pelaksanaan aktivitas kerja mereka sehari-hari.

Dengan demikian, dapat disimpulkan bahwa kinerja adalah hasil atau tingkat keberhasilan, kemampuan, usaha, dan tanggungjawab seseorang dalam melaksanakan pekerjaan dan menyempurnakan hasil pekerjaan sesuai fungsi target atau sasaran serta kriteria yang ditetapkan. 


\section{METODE PENELITIAN}

Populasi dalam penelitian ini adalah para pegawai yang ada di Kantor Kementerian Agama Kabupaten Tebo yang berjumlah 31 orang. Hal ini dikarenakan, jumlah pegawai kurang dari 100 maka semua populasi penelitian dijadikan sampel penelitian.

Sementara, teknik yang digunakan dalam pengumpulan data penelitian ini adalah kuesioner, wawancara, dan observasi. Adapun jenis kuesioner yang digunakan adalah kuesioner langsung dan tertutup dengan menggunakan skala likert. Untuk variabel yang digunakan dalam penelitian ini sendiri, yakni Analisis Jabatan (X1), Pengembangan Karir (X2), Kompetensi (Y), dan Kinerja Pegawai (Z). Sementara, untuk mengukur hasil perolehan data yang didapat dari kuesioner sendiri, digunakan alat analisis, yakni SPSS. Dan, pengolahan tersebut akan digunakan melalui penerapan analisis jalur, baik untuk mengetahui pengaruh langsung maupun tidak langsung antar masing-masing variabel.

\section{HASIL DAN PEMBAHASAN}

\section{Analisis Deskriptif}

Analisis ini bertujuan untuk menggambarkan masing-masing variabel ke dalam tabel distribusi frekuensi, kemudian dilakukan analisis persentase serta memberikan interpretasi terhadap analisis tersebut. Adapun uji analisis dalam penelitian ini dapat dilihat pada tabel, sebagai berikut :

1. Analisis Jabatan (X1), analisis jabatan yang ada di Kantor Kementerian Agama Kabupaten Tebo memiliki skor sebesar 1.844 dengan kategori "sangat baik".

2. Pengembangan Karir (X2), pengembangan karir yang ada di Kantor Kementerian Agama Kabupaten Tebo memiliki skor sebesar 1.210 dengan kategori "sangat baik".

3. Kompetensi (Y), kompetensi pegawai yang ada di Kantor Kementerian Agama Kabupaten Tebo memiliki skor sebesar 1.847 dengan kategori "sangat baik".

4. Kinerja Pegawai (Z), kinerja pegawai yang ada di Kantor Kementerian Agama Kabupaten Tebo memiliki skor sebesar 1.348 dengan kategori "sangat baik".

\section{Pengaruh Analisis Jabatan dan Pengembangan Karir Secara Parsial Terhadap Kompetensi}

Hasil ini menunjukkan bahwa Analisis Jabatan (X1) yang ada di Kantor Kementerian Agama Kabupaten Tebo berpengaruh positif dan signifikan terhadap Kompetensi (Y) dan ini terbukti sehingga hipotesis di terima. Hasil ini menunjukkan bahwa Pengembangan Karir (X2) yang ada di Kantor Kementerian Agama Kabupaten Tebo tidak berpengaruh secara signifikan terhadap Kompetensi (Y) dan ini terbukti sehingga hipotesis di tolak.

\section{Pengaruh Analisis Jabatan dan Pengembangan Karir Secara Simultan Terhadap Kompetensi}

Secara simultan antara variabel Analisis Jabatan (X1) dan variabel Pengembangan Karir (X2) dengan variabel Kompetensi (Y) menunjukkan bahwa $F_{\text {hitung }} 27,746>F_{\text {tabel }} 1,60$, dengan perolehan signifikasi sebesar $0,000<0,05(\alpha=5 \%)$ sehingga hipotesis ini diterima. Hasil ini menunjukkan bahwa Analisis Jabatan (X1) dan Pengembangan Karir (X2) secara 
simultan berpengaruh terhadap Kompetensi (Y) pegawai yang ada di Kantor Kementerian Agama Kabupaten Tebo.

\section{Pengaruh Analisis Jabatan dan Pengembangan Karir Secara Parsial Terhadap Kinerja Pegawai}

Hasil ini menunjukkan bahwa Analisis Jabatan (X1) yang ada di Kantor Kementerian Agama Kabupaten Tebo berpengaruh positif dan signifikan terhadap Kinerja Pegawai (Z) dan ini terbukti sehingga hipotesis di terima. Hasil ini menunjukkan bahwa Pengembangan Karir (X2) yang ada di Kantor Kementerian Agama Kabupaten Tebo berpengaruh signifikan terhadap Kinerja Pegawai (Z) dan ini terbukti sehingga hipotesis di terima.

\section{Pengaruh Analisis Jabatan dan Pengembangan Karir Secara Parsial Terhadap Kinerja Pegawai}

Secara simultan antara variabel Analisis Jabatan (X1) dan variabel Pengembangan Karir (X2) dengan variabel Kinerja Pegawai $(Z)$ menunjukkan bahwa $F_{\text {hitung }} 81,229>F_{\text {tabel }}$ 1,60 , dengan perolehan signifikasi sebesar $0,000<0,05(\alpha=5 \%)$ sehingga hipotesis ini diterima. Hasil ini menunjukkan bahwa secara simultan Analisis Jabatan (X1) dan Pengembangan Karir (X2) secara simultan berpengaruh terhadap Kinerja Pegawai (Z) di Kantor Kementerian Agama Kabupaten Tebo.

\section{Pengaruh Kompetensi Terhadap Kinerja Pegawai}

Kompetensi (Y) dengan variabel Kinerja Pegawai (Z) menunjukkan bahwa t hitung 5,762 dengan nilai Sig. 0,000. Dimana, kriteria keputusan jika Sig. penelitian < 0,05 maka H0 di tolak dan H1 di terima artinya signifikan, tetapi jika Sig. penelitian > 0,05 maka H0 di terima dan H1 di tolak yang berarti tidak signifikan. Karena 0,000 $<0,05$ maka H0 di tolak dan H1 di terima. Hasil ini menunjukkan bahwa Kompetensi (Y) para pegawai yang ada di Kantor Kementerian Agama Kabupaten Tebo berpengaruh positif dan signifikan terhadap Kinerja Pegawai (Z) dan ini terbukti sehingga hipotesis di terima.

\section{KESIMPULAN DAN SARAN}

Adapun hasil dalam penelitian ini menunjukkan bahwa terdapat pengaruh signifikan analisis jabatan, pengembangan karir, dan kompetensi terhadap kinerja pegawai Kantor Kementerian Agama Kabupaten Tebo. Dengan demikian, dapat dikatakan bahwa dengan adanya analisis jabatan yang tepat dan memberikan kesempatan dalam mengembangkan karir para pegawai itu sendiri maka secara tidak langsung akan meningkatkan kompetensi yang ada pada diri masing-masing pegawai yang pada akhirnya akan lebih optimal dalam memberikan yang terbaik bagi organisasi itu sendiri dengan cara peningkatan kinerja yang lebih baik dari sebelumnya.

Adapun saran yang dapat dikemukakan dalam penelitian ini, antara lain sebagai berikut: Untuk keperluan akademis perlu kiranya dilakukan penelitian lebih lanjut tentang pengaruh analisis jabatan, pengembangan karir, dan kompetensi terhadap kinerja pegawai untuk menguji kesahihan hasil penelitian ini dan untuk menambah cakrawala pengembangan ilmu manajemen sumber daya manusia. 


\section{DAFTAR PUSTAKA}

Bernadin \& Russel. 2002. "Fundamental Organization Behavior", Diterjemahkan Agus Dharma. Jakarta : Erlangga.

Feldam, Charvert, 2005. “The Good Perspective of HRM”. Prentice Hall : Ohio University Press.

Gibson, J.L., J.M. Ivancevich, dan J.H. Donnelly. 2003. “Organizations, Behavior, Structure, Processes". Alih bahasa oleh Djoerban Wahid. Jakarta : Erlangga.

Jusuf, Irianto. 2001. "Prinsip-prinsip Dasar Manajemen Pelatihan (Dari Analisis Kebutuhan Sampai Evaluasi Program Pelatihan)”. Jakarta : Insani Cendekia.

Kessler, Robin. 2011. "Competency Based Performance Reviews". Jakarta : PPM.

Mathis, Robert L. \& John H. Jackson. 2007. “Manajemen Sumber Daya Manusia”. Jakarta : Salemba Empat.

Rivai, V dan A.F Mohd. Basri. 2005. "Performance Appraisal”. Jakarta : RajaGrafindo Persada.

Sirait T.J. 2006. "Memahami Aspek-Aspek Pengelolaan Sumber Daya Manusia Dalam Organisasi”. Jakarta : Grasindo.

Wibowo. 2010. “Manajemen Kinerja”. Jakarta : Raja Grafindo Persada. 